\title{
Seasonal movements of yellow-phase American eels ( Anguilla rostrata) in the Shenandoah River, West Virginia
}

\author{
Stephen D. Hammond \\ West Virginia University
}

Follow this and additional works at: https://researchrepository.wvu.edu/etd

\section{Recommended Citation}

Hammond, Stephen D., "Seasonal movements of yellow-phase American eels ( Anguilla rostrata) in the Shenandoah River, West Virginia" (2003). Graduate Theses, Dissertations, and Problem Reports. 1778. https://researchrepository.wvu.edu/etd/1778

This Thesis is protected by copyright and/or related rights. It has been brought to you by the The Research Repository @ WVU with permission from the rights-holder(s). You are free to use this Thesis in any way that is permitted by the copyright and related rights legislation that applies to your use. For other uses you must obtain permission from the rights-holder(s) directly, unless additional rights are indicated by a Creative Commons license in the record and/ or on the work itself. This Thesis has been accepted for inclusion in WVU Graduate Theses, Dissertations, and Problem Reports collection by an authorized administrator of The Research Repository @ WVU. For more information, please contact researchrepository@mail.wvu.edu. 
Seasonal movements of yellow-phase American eels (Anguilla rostrata) in the Shenandoah River, West Virginia

\title{
Stephen D. Hammond
}

Thesis submitted to the Davis College of Agriculture, Forestry, and Consumer Sciences at West Virginia University in partial fulfillment of the requirements

for the degree of

Master of Science

in

Wildlife and Fisheries Resources

\author{
Stuart A. Welsh, Ph.D., Chair \\ Kerry Bledsoe, M.S. \\ Douglas A. Dixon, Ph.D. \\ Kyle J. Hartman, Ph.D. \\ Patricia Mazik, Ph.D.
}

Division of Forestry

Morgantown, WV

2003

Keywords: American eel (Anguilla rostrata), seasonal movements, radio telemetry, eel passage, hydroelectric dam effects, catadromous, Shenandoah River 


\begin{abstract}
Seasonal movements of yellow-phase American eels (Anguilla rostrata) in the Shenandoah River, West Virginia.
\end{abstract}

\title{
Stephen D. Hammond
}

Yellow-phase American eels undergo extensive upstream migration in Atlantic coastal river systems. Few studies, however, have focused on movements of large yellow-phase American eels near dams in upper watersheds of Atlantic coastal rivers. We examined relationships between environmental variables (stream flow, water temperature, and lunar phase) and movements of radio-tagged yellow-phase American eels (518 - $810 \mathrm{~mm}$ TL) near Millville hydroelectric dam in the lower Shenandoah River drainage, West Virginia (an upper watershed of the Potomac River system). Movements of yellow-phase American eels differed among seasons. Increased water temperature and stream flow were associated with upstream migration during spring. Downstream movements during fall corresponded with decreasing water temperatures and darker nights near the new moon, where eels located and overwintered in thermal refuge areas near tributary mouths. Localized wandering (upstream and downstream movements) during summer occurred near dusk and dawn, and possibly reflected nocturnal foraging. In relation to hydroelectric facilities and eel passage within the Potomac River drainage, our data support a need for upstream passage during spring when water temperatures exceed $15^{\circ} \mathrm{C}$. 


\section{DEDICATION}

To my parents, and Rebecca 


\section{ACKNOWLEDGEMENTS}

I would like to extend thanks to the members of my graduate committee, especially Dr. Stuart Welsh for his guidance, Dr. Douglas Dixon, Kerry Bledsoe, Dr. Kyle Hartman, and Dr. Pat Mazik, for their contributions during this project.

Funding was provided through EPRI (Electric Power Research Institute) of Palo Alto, California, Allegheny Energy, and West Virginia Division of Natural Resources.

Special thanks and appreciation to Terry Euston, Ben Lenz, Lara Hedrick, Jessica Smith, and Dave Wellman for their assistance with fieldwork and data collection, and Melody Danley, Barbara Douglas, Larry Earnest, Terry Euston, Gary Harbaugh, Alex Hoar, Mike Mangold, Charles Simons, and Julie Weeder for their contributions to the project.

Thank you Linda Tolka for accommodating many last minute requests, and Becky Nestor for radio-telemetry headgear design.

A final thanks to John Gill, Rudy Lukacovic, and Julie Weeder for their letters of recommendation. 


\section{TABLE OF CONTENTS}

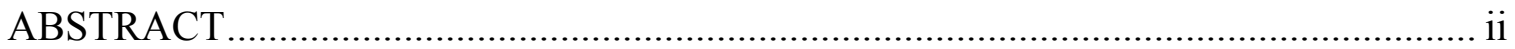

DEDICATION

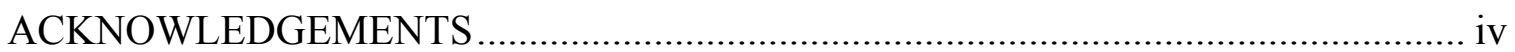

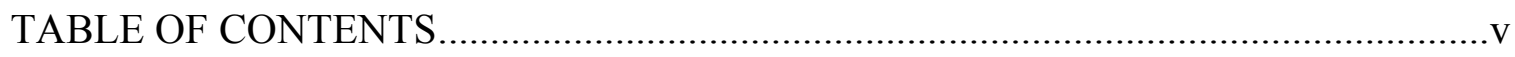

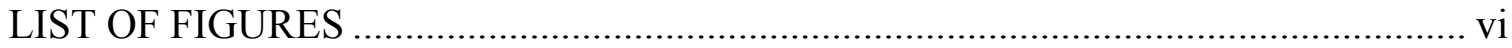

LIST OF TABLES ......................................................................................... vii

CHAPTER 1: LITERATURE REVIEW ….............................................................

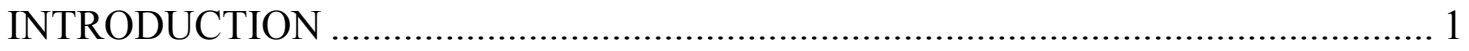

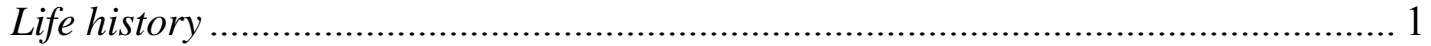

Spawning migration ........................................................................................ 2

Freshwater movement studies............................................................................. 3

Local and seasonal movements of yellow-phase eels ............................................ 3

Effects of dams on upstream and downstream migration ..................................... 4

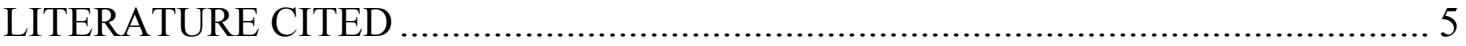

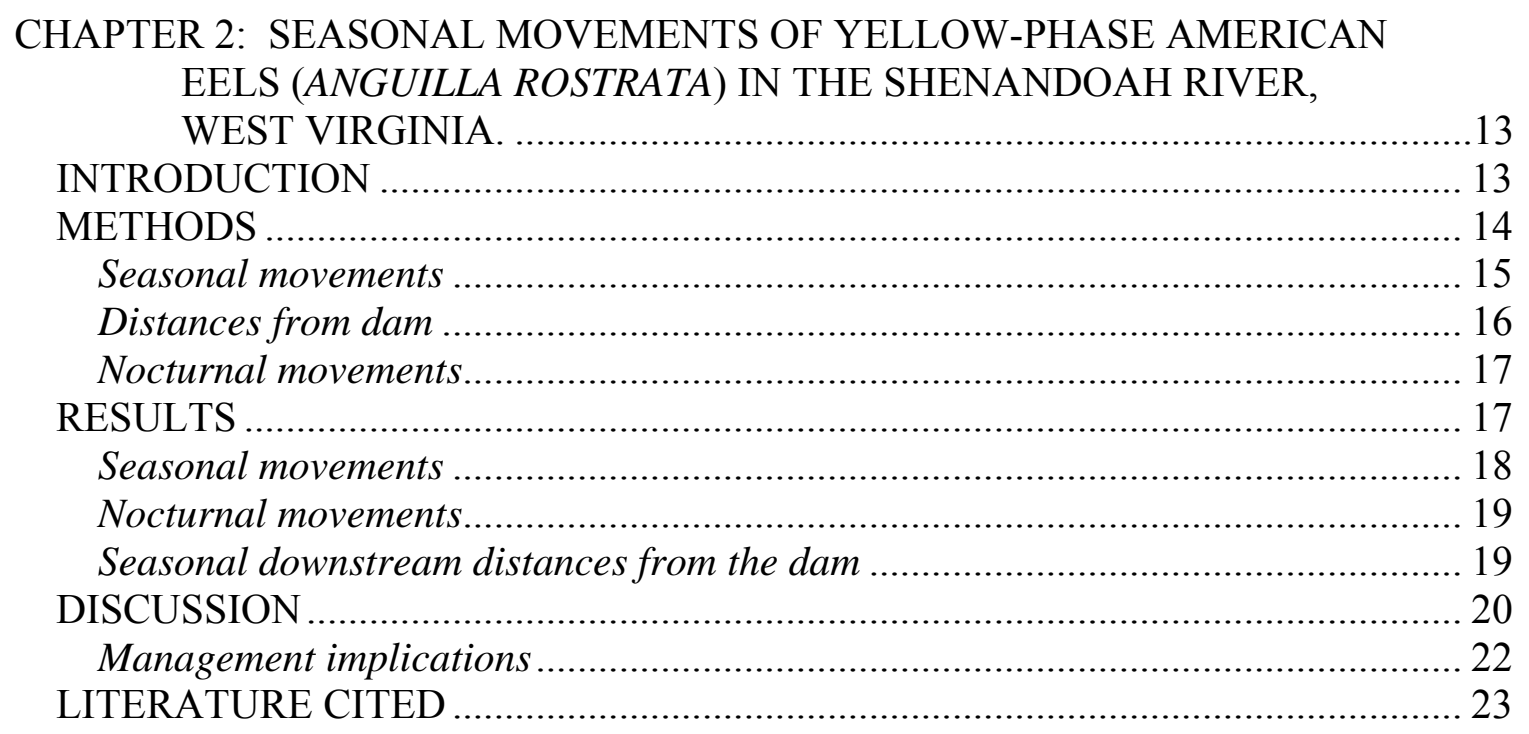




\section{LIST OF FIGURES}

Figure 1. Study area within a $9 \mathrm{~km}$ section of the lower Shenandoah River, West Virginia, from Millville Dam to the mouth of the Shenandoah River..

Figure 2. Seasonal distance of radio-tagged American eels from Millville Dam (all relocations plotted for each eel)................................................................... 30 


\section{LIST OF TABLES}

Table 1. Selection statistics for 24 alternative models from separate analyses of upstream and downstream movements; second order adjustment of Akaike's Information Criterion $\left(\mathrm{AIC}_{c}\right)$, distance from lowest $\mathrm{AIC}_{c}\left(\Delta_{i}\right)$, and Akaike weights $\left(\mathrm{w}_{i}\right)$. Bold weights represent competing models within each analysis; statistics between upstream and downstream analyses are not comparable. Model variables include season (movements partitioned by spring, summer, fall, and winter), and six covariates determined from each relocation interval: maximum and mean stream flow, maximum and mean water temperature, maximum lunar illumination, and fluctuations of stream flow and water temperature.

Table 2. Selection statistics for 5 alternative models of nocturnal movements during six summer nights; second order adjustment of Akaike's Information Criterion $\left(\mathrm{AIC}_{c}\right)$, distance from lowest $\mathrm{AIC}_{c}\left(\Delta_{i}\right)$, and Akaike weights $\left(\mathrm{w}_{i}\right)$. Movements $(\mathrm{m} / \mathrm{hr})$ were estimated within four 2-hour time periods (21002300, 2300-0100, 0100-0300, and 0300-0500 hours), where models represent movements associated with dusk (2100-2300 hours), dawn (03000500 hours), dusk and dawn, and lunar illumination. 


\section{CHAPTER 1: LITERATURE REVIEW INTRODUCTION}

The complex life history of the catadromous American eel, Anguilla rostrata (LeSueur), is not clearly understood. Many unanswered questions remain for all life stages of the American eel (larval, glass eel, elver, yellow, and silver). Although reproductive biology is probably least understood (Fontaine et al. 1982, Tsukamoto et al. 1998, EPRI 1999), information on estuarine and freshwater life stages is needed for management and protection of declining eel populations. Studies have shown dramatic declines in numbers and juvenile recruitment since the early 1980s in American and European eel (Anguilla anguilla) populations (Castonguay et al. 1994a, De Leo and Gatto 1996, Dekker 2000, Haro et al. 2000, Ing 2000, Richkus and Whalen 2000, Feunteun 2002). American and European eels use a wide range of habitats, which allows many opportunities for detrimental effects on the populations. Although exact causes of decline are unknown, Castonguay et al. (1994b) and Knights (2003) proposed several possible factors, including oceanic and climatic changes, chemical contamination, major habitat modifications, hydroelectric impacts, and over-fishing. Below I review scientific summaries of eel biology and behavior, with emphasis on migration and movements of yellow-phase eels, and potential impacts of dams.

\section{Life history}

American eels are distributed widely along the North American Atlantic coast and Gulf of Mexico (Helfman et al. 1987), but occur as far south as the Virgin Islands (Boëtius 1980) and Venezuela, to northern areas near Greenland (Tesch 1977, Jenkins and Burkhead 1993). American eels begin and end life in areas of the Sargasso Sea (Schmidt 1925, Vladykov 1964). After hatching, the larvae (leptocephali) drift westward and northward with the ocean currents of the Gulf Stream for up to a year (Kleckner and McCleave 1985) and metamorphose into "glass eels" before entry into estuaries. Glass eels begin to develop pigmentation as they mature into "elvers" (Haro and Krueger 1988), and become "yellow-phase eels" after exceeding approximately $100 \mathrm{~mm}$ total length. 
The yellow-phase predominates the life cycle, where eels inhabit estuaries or undergo extensive migration up rivers (Tesch 1977, Moriarty 1978). Yellow-phase eels occur throughout river systems including upper watersheds with high gradients (Jenkins and Burkhead 1993). Higher percentages of males in lower river systems and estuaries, and higher percentages of females in upper watersheds may be associated with densitydependent factors (Helfman et al. 1987). Many factors, including environmental factors, especially eel population densities, may be significantly involved in sex determination, with areas of high density dominated by males, and areas of lower density dominated by females (Krueger and Oliveira 1999). The gender of adult eels is not externally apparent, and histological examination of tissues is necessary for sex determination (Dolan and Power 1977, Facey and LaBar 1981). Males have slower growth, shorter life span, and attain smaller sizes than females (Tesch 1977, Helfman et al 1987, Krueger and Oliveira 1997, Oliveira 1997). Female yellow-phase eels have attained ages of at least 30 years (Jessop 1987) before reaching reproductive maturity, and have been shown to mature at greater ages and sizes in the northern range of their distribution (Helfman et al. 1987).

\section{Spawning migration}

Yellow-phase eels transform into a "silver-phase" during or before spawning migration to the Sargasso Sea (Vladykov 1973, Wenner and Musick 1974, Winn et al. 1975, Kleckner et al. 1983). Seaward migration occurs generally from September through December (Vøllestad et al. 1986, Helfman et al. 1987), where eels undergo a number of physiological changes as they metamorphose into the "silver-phase." External changes include pigmentation change from olive-yellow into a bright silvery color, and a substantial increase in eye diameter (Vladykov 1973, Werner and Musick 1974, Boëtius and Boëtius 1980), as well as development of the lateral line (Zacchei and Tavolaro 1988). Internally, functional morphology and physiology of the swim bladder may change (Kleckner and Krueger 1981), and degeneration of the alimentary tract and feeding cessation may occur (Pankhurst and Sorensen 1984). Spawning migration culminates in areas of the Sargasso Sea, although spawning behavior is undocumented (EPRI 1999). 
Research on American eels and European eels, which share similar behavioral, ecological, and life history characteristics (EPRI 1999), indicate environmental influences on upstream and downstream migration, as well as localized movements. Researchers have reported downstream migration of silver-phase eels in association with water temperature, precipitation, stream flow, turbidity, incident light, and lunar phase (Lowe 1952, Smith and Saunders 1955, Winn et al. 1975, Tesch 1977, Haraldstad et al. 1985, Vøllestad et al. 1986, Bergersen and Klemetsen 1988, Euston et al. 1997, EPRI 2001). Migration of silver eels from estuary to ocean may involve olfaction (Barbin et al. 1998).

\section{Freshwater movement studies}

Upstream migration and localized movements of juvenile and yellow-phase American eels are also correlated with environmental factors. Water temperature influences upstream movement of elvers (Sorensen and Bianchini 1986; Haro and Krueger 1988; Martin 1995). Sorensen and Bianchini (1986) showed initial upstream movement of elvers between 12 and $19^{\circ} \mathrm{C}$, and Haro and Krueger (1988) showed movement between 10.5 and $21.5^{\circ} \mathrm{C}$. Daily eel catch data from 1990-1992 from a fish lift at the Conowingo Dam on the Susquehanna River, Maryland, showed first catches occurred between 12 and $15^{\circ} \mathrm{C}$ (SRAFRC 1991, 1992, 1993).

River flow and lunar phase also influence eel movements. Fluctuations or sudden changes in water temperature or stream flow within short time intervals may elicit eel movements (Durif et al. 2003, Verdon et al. 2003). Eel activity (both local and long distance migratory movements) increase during periods of reduced moon illumination of the new moon phases (Lowe 1952, Winn et al. 1975, Lamothe et al. 2000, Cairns and Hooley 2003).

\section{Local and seasonal movements of yellow-phase eels}

Few studies have focused on seasonal movements of yellow-phase American eels in freshwater systems. Researchers have reported punctuated periods of upstream migration, where large yellow-phase eels generally migrate upstream during spring, but exhibit local movements during other seasons (Bianchini et al. 1982, Oliveira 1997). Yellow-phase eels, however, migrate upstream during summer and fall in the St. 
Lawrence River (McGrath et al. 2003). Strickland (2002) found that yellow-phase eels in the James River, Virginia, were most active during warmer months (May-October), and moved little during winter. At winter water temperatures below $10^{\circ} \mathrm{C}$, movements are reduced when eels become torpid (Walsh et al. 1983).

Within seasons, non-migratory, localized and wandering movements of yellowphase eels in rivers and estuaries are probably associated with food density, habitat type, eel abundance, and interactions with conspecifics (Ford and Mercer 1986, Helfman 1986). Movements in estuarine areas are influenced by tidal stages (Dutil et al. 1988). Eels may establish home ranges (Gunning and Shoop 1962, Hurley 1972, Helfman 1986, Dutil et al. 1988, Oliveira 1997), and some studies support homing behavior (LaBar and Facey 1983, Parker 1995, Lemothe et al. 2002). Although American eels have diverse diets (Ogden 1970, Werner and Musick 1975, Wilson and Turner 1982, Lookabaugh and Angermeier 1992), and foraging modes (Helfman and Clark 1986, Helfman and Winkelman 1991), the distribution and availability of forage likely influences local movements (Helfman 1986). Eels are nocturnal and use cover during daylight hours (Baras et al. 1998), so availability and abundance of cover habitat in relation to food availability also likely influences localized movements. Additionally, intraspecific competition for cover and food in densely populated areas may influence movements at a local scale (Helfman 1986).

\section{Effects of dams on upstream and downstream migration}

Dams may directly or indirectly impact eel populations, and contribute to the apparent overall population decline (EPRI 1999). Dams may detain upstream movements of elvers and yellow eels, and disrupt downstream migration of sexually mature silver eels. Passage through hydroelectric turbines is a conservation concern for downstream migrants (EPRI 1999, EPRI 2001, Coutant and Whitney 2000, Haro and Castro-Santos 2000), but is not reviewed herein, given the thesis focus of yellow-phase eels. Dams may indirectly impact eels by fragmenting habitat, changing the amount of habitat types, and altering eel movement and migration through habitat changes from natural riverine conditions to slow-moving lacustrine habitats (EPRI 1999). Additionally, dams may 
influence sex ratios, given that eels in upstream river sections typically differentiate as females (Krueger and Oliveira 1999).

Fisheries managers and researchers have implemented and studied several methods to mitigate or reduce effects of dams on upstream migration (EPRI 1999). Eel ladders, specifically designed for eel passage, effectively facilitate upstream movement of eels (Whitfield and Kolenosky 1978, Eckersley 1982, Liew 1982). EPRI (1999) describes specific details of eel-passage requirements for upstream migrating eels. Small eels $(<100 \mathrm{~mm})$ are able to ascend simple wetted passageways and pipes with adequate substrate to provide friction for climbing, such as gravel or mesh material. Larger yellow-phase eels require different substrates than smaller eels. Small vertical rods and tubes placed in the bottom of passageways have worked successfully for larger eels (EPRI 1999).

This thesis documents studies of seasonal and nocturnal movements of large (518 - 810 mm TL) yellow-phase American eels in the Shenandoah River below Millville Dam, West Virginia. The results have implications for operational management of hydroelectric facilities, given few studies on movements of large yellow-phase American eels near dams in upper watersheds of Atlantic coastal rivers.

\section{LITERATURE CITED}

Atlantic States Marine Fisheries Commission. 2000. Interstate fishery management plan for American eel (Anguilla rostrata). Washington, D.C.

Baras, E., D. Jeandrain, B. Serouge, and J. C. Philippart. 1998. Seasonal variations in time and space utilization by radio-tagged yellow eels Anguilla anguilla (L.) in a small stream. Hydrobiologia 371-372(1-3):187-198.

Barbin, G. P., S. J. Parker, J. D. McCleave. 1998. Olfactory clues play a critical role in the esturine migration of silver-phase American eels. Environmental Biology of Fishes 53:283-291.

Bergersen, R. and A. Klemetsen. 1988. Freshwater eel Anguilla anguilla (L.) from North Norway, with emphasis on occurrence, food, age, and downstream migration. Nordic Journal of Freshwater Research 64:54-66.

Bianchini, M., P.W. Sorensen, and H.E. Winn. 1982. Stima dell'abbondanza e shemi di movimento a breve raggio della anguilla Americana, Anguilla rostrata 
(LeSueur)(Pisces, Apodes), nel Narrow River, Rhode Island, USA. Naturalista Siciliano (Supplement 4) 6:269-277.

Boëtius, J. 1980. Atlantic Anguilla. A presentation of old and new data of total numbers of vertebrae with special reference to the occurrence of Anguilla rostrata in Europe. Dana 1:93-112.

Boëtius, I. and J. Boëtius. 1980. Experimental maturation of female silver eels, Anguilla anguilla: estimates of fecundity and energy reserves for migration and spawning. Dana 1:1-28.

Cairns, D. K. and P. J. D. Hooley. 2003. Lunar cycles of American eels in tidal waters of the southern Gulf of the St. Lawrence, Canada. Pages 265-274 in D.A. Dixon, editor. Biology, Management, and protection of catadromous eels. American Fisheries Society, Symposium 33, Bethesda, Maryland.

Castonguay, M., P. V. Hodson, and C. M. Couillard. 1994a. Why is recruitment of the American eel, Anguilla rosrata, declining in the St. Lawrence River and Gulf? Canadian Journal of Fisheries and Aquatic Science 51:479-488.

Castonguay, M., P. V. Hodson, C. Moriarty, K. F. Drinkwater, and B. M. Jessop. 1994 b. Is there a role of ocean environment in American and European eel decline? Fisheries Oceanography 3(3):197-203.

Coutant, C.C. and R.R. Whitney. 2000. Fish behavior in relation to passage through hydropower turbines: a review. Transactions of the American Fisheries Society 129:351-380.

De Leo, G. A. and M. Gatto. 1996. Trends in vital rates of the European eel: evidence for density dependence? Ecological Applications 6(4):1281-1294.

Dekker, W. 2000. Insufficient spawning stock is a sufficient explanation of the recruitment decline in the European eel. Netherlands Institute for Fisheries Research, IJmuiden, the Netherlands.

Dolan, J. A. and G. Power. 1977. Sex ratio of American eels, Anguilla rostrata, from the Matamek River system, Quebec, with remarks on problems in sexual identification. Journal of the Fisheries Research Board of Canada 34:294-299.

Durif, C., P. Elie, C. Gosset, J. Rives, and F. Travade. 2003. Behavioral study of downstream migrating eels by radio-telemetry at a small hydroelectric power 
plant. Pages 343-356 in D.A. Dixon, editor. Biology, Management, and protection of catadromous eels. American Fisheries Society, Symposium 33, Bethesda, Maryland.

Dutil, J-D., A. Giroux, A. Kemp, G. Lavoie, and J-P. Dallaire. 1988. Tidal influence on movements and on daily cycle of activity of American eels. Transactions of the American Fisheries Society 117(5):488-494.

Eckersley, M. J. 1982. Proceedings of the 1980 North American eel conference. Ontario Fisheries Technical Series Number 4. Ontario Ministry of Natural Resources, Fisheries Branch, Toronto, Ontario.

EPRI (Electrical Power Research Institute). 1999. American eel (Anguilla rostrata) scooping study: a literature and data review of life history, stock status, population dynamics, and hydroelectric impacts. EPRI, Palo Alto, California: TR111873.

EPRI (Electrical Power Research Institute). 2001. Review and documentation of research and technologies on passage and protection of downstream migrating catadromous eels at hydroelectric facilities. EPRI, Palo Alto, California: TR1000730.

Euston, E. T., D. D. Royer, and C. L. Simons. 1997. Relationship of emigration of silver American eels (Anguilla rostrata) to environmental variables at a low head hydro station. Proceedings of the International Conference on Hydropower, August 5-8, 1997, Atlanta, Georgia.

Facey, D. E. and G. W. LaBar. 1981. Biology of American eels in Lake Champlain, Vermont. Transactions of the American Fisheries Society 110:396-402.

Feunteun, E. 2002. Management and restoration of European eel population (Anguilla anguilla): An impossible bargain. Ecological Engineering 18(5):575-591.

Fontaine, M., N. Delerue-LeBelle, F. Lallier, and E. Lopez. 1982. Do all eels die after reproduction and do they necessarily spawn at sea? C. R. Academy of Science, Paris (1)294 series 3:809-811.

Ford, T. E. and E. Mercer. 1986. Density, size distribution and home range of American eels, Anguilla rostrata, in a Massachusetts salt marsh. Environmental Biology of Fishes 17:309-314. 
Gunning, G.E. and C.R. Shoop. 1962. Restricted movements of the American eel, Anguilla rostrata (LeSueur), in freshwater streams, with comments on growth rate. Tulane Studies in Zoology 9:265-272.

Haraldstad, Ø., L. A. Vøllestad, and B. Johnson. 1985. Descent of European silver eels, Anguilla anguilla L., in a Norwegian watercourse. Journal of Fish Biology 26:3741.

Haro, A. J. and W. H. Krueger. 1988. Pigmentation, size and migration of elvers (Anguilla rostrata (LeSueur)) in a coastal Rhode Island stream. Canadian Journal of Zoology 66:2528-2533.

Haro, A. and T. Castro-Santos. 2000. Behavior and passage of silver-phase American eels, Anguilla rostrata(LeSueur), at a small hydroelectric facility. Dana 12:33-42.

Haro, A., W. Richkus, K. Whalen, A. Hoar, W-D. Busch, S. Lary, T. Brush, and D. Dixon. 2000. Population decline of the American eel: implications for research and management. Fisheries 25(9):7-16.

Helfman, G. S. 1986. Diel distribution and activity of American eels (Anguilla rostrata) in a cave-spring. Canadian Journal of Fisheries and Aquatic Sciences 43:15951605.

Helfman, G. S. and J. B. Clark. 1986. Rotational feeding: overcoming gape-limited foraging in anguillid eels. Copeia 1986:679-685.

Helfman, G. S., D. E. Facey, L. S. Hales, Jr., and E. L. Bozeman, Jr. 1987. Reproductive ecology of the American eel. American Fisheries Society Symposium 1:42-56.

Helfman, G. S. and D. L. Winkelman. 1991. Energy trade-offs and foraging mode choice in American eels. Ecology 72(1):310-318.

Hurley, D. A. 1972. The American eel (Anguilla rostrata) in eastern Lake Ontario. Journal of the Fisheries Research Board of Canada 29:535-543.

Ing, B. I. 2000. The decline of the American eel (Anguilla rostrata) in the Lake Ontario/St. Lawrence River ecosystem: A modeling approach to identification of data gaps and research priorities. Lake Ontario Technical Committee Great Lakes Fishery Commission, Brampton, Ontario.

Jenkins, R. E. and N. M. Burkhead. 1993. Freshwater fishes of Virginia. American Fisheries Society, Bethesda, Maryland. 
Jessop, B. M. 1987. Migrating American eels in Nova Scotia. Transactions of the American Fisheries Society 116:161-170.

Kleckner, R. C. and W. H. Krueger. 1981. Changes in swin bladder retial morphology in Anguilla rostrata during premigration metamorphosis. Journal of Fish Biology 18:569-577.

Kleckner, R. C., J. D. McCleave, and G. S. Whipplehauser. 1983. Spawning of American eel, Anguilla rostrata, relative to thermal fronts in the Sargasso Sea. Environmental Biology of Fishes 9:289-293.

Kleckner, R. C. and J. D. McCleave. 1985. Spatial and temporal distribution of American eel larvae in relation to North Atlantic Ocean current systems. Dana 4: $67-92$.

Knights, B. 2003. The review and possible impacts of long-term oceanic and climate changes and fishing mortality on recruitment of anguillid eels of the Northern Hemisphere. The Science of the Total Environment 310:237-244.

Kreuger, W. H. and K. Oliveira. 1997. Sex, size, and gonad morphology of silver American eels Anguilla rostrata. Copeia 1997(2):415-420.

Kreuger, W. H. and K. Oliveira. 1999. Evidence for environmental sex determination in the American eel, Anguilla rostrata. Environmental Biology of Fishes 55:381389.

LaBar, G. W. and D. E. Facey. 1983. Local movements and inshore population sizes of American eels in Lake Champlain, Vermont. Transactions of the American Fisheries Society 112:111-116.

Lamothe, P. J., M. Gallagher, D. P. Chivers, and J. M. Moring. 2000. Homing and movement of yellow-phase American eels in freshwater ponds. Environmental Biology of Fishes 58:393-399.

Liew, P. K. L. 1982. Proceedings of the 1980 North American eel conference. Ontario Fisheries Technical Report Series Number 4. Ontario Ministry of Natural Resources, Fisheries Branch, Toronto, Ontario.

Lookabaugh, P. S. and P. L. Angermeier. 1992. Diet patterns of American Eel, Anguilla rostrata, in the James River drainage, Virginia. Journal of Freshwater Ecology $7(4): 425-434$. 
Lowe, R. H. 1952. The influence of light and other factors on the seaward migration of the silver eel, Anguilla anguilla L. Journal of Animal Ecology 21:275-309.

Martin, M. H. 1995. The effects of temperature, river flow, and tidal cycles on the onset of glass eel and elver migration into fresh water in the American eel. Journal of Fish Biology 46:891-902.

McGrath, K.J., D. Desrochers, C. Fleury, and J.W. Dembeck, IV. 2003. Studies of upstream migrant American eels at the Moses-Saunders Power Dam on the St. Lawrence River near Massena, New York. Pages 153-166 in D.A. Dixon, editor. Biology, Management, and protection of catadromous eels. American Fisheries Society, Symposium 33, Bethesda, Maryland.

Moriarty, C. 1978. Eels: a natural and unnatural history. Universe Books, New York, New York.

Ogden, J. C. 1970. Relative abundance, food habits, and age of the American eel, Anguilla rostrata (LeSueur), in certain New Jersey streams. Transactions of the American Fisheries Society 1:54-59.

Oliveira, K. 1997. Movement and growth rates of yellow-phase American eels in the Annaquatucket River, Rhode Island. Transactions of the American Fisheries Society 126:638-646.

Pankhurst, N. W. and P. W. Sorensen. 1984. Degeneration of the alimentary tract in sexually maturing European Anguilla anguilla (L.) and American eels Anguilla rostrata (LeSueur). Canadian Journal of Zoology 62:1143-1149.

Parker, S. J. 1995. Homing ability and home range of yellow-phase American eels in a tidally dominated estuary. Journal of the Marine Biological Association of the United Kingdom 75:127-140.

Richkus, W. and K. Whalen. 2000. Evidence for a decline in the abundance of the American eel Anguilla rostrata (LeSueur), in North America since the early 1980s. Dana 12:83-97.

Schmidt, J. 1925. The breeding places of the eel. Annual Report of the Smithsonian Institution 1924, Washington, D.C. 
Smith, M. W. and J. W. Saunders. 1955. The American eel in certain fresh waters of the Maritime Provinces of Canada. Journal of the Fisheries Research Board of Canada 12:238-269.

Sorensen, P. W. and M. L. Bianchini. 1986. Environmental correlates of the freshwater migration of elvers of the American eel in a Rhode Island brook. Transactions of the American Fisheries Society 115:258-268.

Strickland, P. A. 2002. American eel distribution and growth in selected tributaries of the James River. Master's thesis, Virginia Polytechnic Institute and State University, Blacksburg, Virginia.

SRAFRC (Susquehanna River Anadromous Fish Restoration Committee). 1991. Restoration of American shad to the Susquehanna River. Annual progress report 1990. Susquehanna River Commission, Harrisburg, Pennsylvania.

SRAFRC (Susquehanna River Anadromous Fish Restoration Committee). 1992. Restoration of American shad to the Susquehanna River. Annual progress report 1991. Susquehanna River Commission, Harrisburg, Pennsylvania.

SRAFRC (Susquehanna River Anadromous Fish Restoration Committee). 1993. Restoration of American shad to the Susquehanna River. Annual progress report 1992. Susquehanna River Commission, Harrisburg, Pennsylvania.

Tecsh, F.-W. 1977. The eel. Chapman and Hall Ltd., London, England.

Tsukamoto, K., I. Nakai, and W.-V. Tesch. 1998. Do all freshwater eels migrate? Nature 396(6712):635-636.

Verdon, R., D. Desrochers, and P. Dumont. 2003. Recruitment of American eels in the Richelieu River and Lake Champlain: provision of upstream passage as a regional-scale solution to a large-scale problem. Pages 125-138 in D.A. Dixon, editor. Biology, Management, and protection of catadromous eels. American Fisheries Society, Symposium 33, Bethesda, Maryland.

Vladykov, V. D. 1964. Quest for the true breeding area of the American eel. (Anguilla rostrata LeSueur). Journal of the Fisheries Research Board of Canada 21:15231530.

Vladykov, V. D. 1973. Macrophthalmia in the American eel (Anguilla rostrata). Journal of the Fisheries Research Board of Canada 30:689-693. 
Vøllestad, L. A. B. Johnson, N. A. Hridsten, T. F. Naesje, O. Haraldstad, and J. RuudHansen. 1986. Environmental factors regulating the seaward migration of European silver eels (Anguill anguilla). Canadian Journal of Fisheries and Aquatic Sciences 43:1909-1916.

Walsh, P.J., G.D. Foster, and T.W. Moon. 1983. The effects of temperature on metabolism of the American eel Anguilla rostrata (LeSueur): compensation in the summer and torpor in the winter. Physiological Zoology 56:532-540.

Wenner, C. A. and J. A. Musick. 1974. Fecundity and gonad observations of the American eel, Anguilla rostrata, migrating from Chesapeake Bay, Virginia. Journal of the Fisheries Research Board of Canada 31:1387-1391.

Werner, C. A. and J. A. Musick. 1975. Food habits and seasonal abundance of the American eel (Anguilla rostrata, from the lower Chesapeake Bay. Chesapeake Science 16(1):62-66.

Whitfield, R. E. and D. P. Kolenosky. 1978. Prototype eel ladder in the St. Lawrence River. The Progressive Fish-Culturist 40(4), 152-154.

Wilson, J. L. and D. A. Turner. 1982. Occurrence of the American eel in the Holston River, Tennessee. Journal of the Tennessee Academy of Science 57(1):63-64.

Winn, H. E., W. A. Richkus, and L. K. Winn. 1975. Sexual dimorphism and natural movements of the American eel (Anguilla rostrata) in Rhode Island streams and estuaries. Helgoländer Wissenschaftliche Meeresuntersuchungen 27:156-166.

Zacchei, A. M. and P. Tavolaro. 1988. Lateral line system during the life cycle of Anguilla anguilla (L.). Bollettino di Zoologia 55(3):145-153. 


\section{CHAPTER 2: SEASONAL MOVEMENTS OF YELLOW-PHASE AMERICAN EELS (ANGUILLA ROSTRATA) IN THE SHENANDOAH RIVER, WEST VIRGINIA.}

\section{INTRODUCTION}

Upstream migration is an important part of the yellow-phase life stage of American eels (ASMFC 2000). Dams undoubtedly detain upstream migration and may contribute to the apparent population decline of American eels (Richkus and Whalen 2000, Haro et al. 2000). However, populations persist upstream of dams in upper watersheds of Atlantic coastal rivers (Menhinick 1991, Jenkins and Burkhead 1994, Goodwin and Angermeier 2003). Eel ladders, often installed as a hydroelectric license condition, have assisted upstream passage in some Atlantic coastal rivers, but movements of yellow-phase eels near dams (with or without eel ladders) are not fully understood (EPRI 1999). A better understanding of eel behavior within and downstream of dam tailwaters, and evaluations of environmental cues for upstream migration are needed for management and protection of yellow-phase American eels.

Data are available on movements of American eels in large rivers (Levesque and Whitworth 1987, Oliveira 1997, Verdon and Desrochers 2003, McGrath et al. 2003), streams (Gunning and Shoop 1962), lakes (Hurley 1972, LeBar and Facey 1983, Lamothe et al. 2000), and estuaries (Helfman et al. 1983, Bozeman et al 1985, Ford and Mercer 1986, Dutil et al. 1989, Barbin et al. 1998). Eel movements differ among seasons (Richkus and Dixon 2003) and are possibly triggered by environmental cues, such as water temperature (McGrath et al. 2003, Verdon et al. 2003), precipitation (Tesch 1977, Winn et al. 1975), flow (Euston et al. 1998), and lunar phase (Lowe 1952, Winn et al. 1975, Cairns and Hooley 2003). Movements may be associated with specific environmental thresholds; water temperatures between 10 and $16^{\circ} \mathrm{C}$ cue upstream movements during spring (Smith and Saunders 1955, Groom 1975, Sorensen and Bianchini 1986, Jessop 2003). Fluctuations or sudden changes in water temperature or stream flow within short time intervals may also elicit eel movements (Durif et al. 2003, Verdon et al. 2003). Most studies of American eel movements have focused on small juveniles within or near estuaries (Sorensen and Bianchini 1986, Haro and Krueger 1987, Dutil et al. 1989), or on larger eels (> $300 \mathrm{~mm} \mathrm{TL}$ ) in lower sections of coastal

This chapter is written in the style of Transactions of the American Fisheries Society 
watersheds (Jessop 1987, Dutil et al. 1988). Little information, however, exists on seasonal movements of relatively large ( $>500 \mathrm{~mm} \mathrm{TL})$ yellow-phase eels in upper watersheds, or on seasonal movements of yellow-phase eels near dams. Data on eel movements are needed to increase our understanding of eel behavior in upper river sections, and to assist operational management of hydroelectric facilities in relation to eel passage.

The primary objective of this study was to examine potential environmental cues (stream flow, water temperature, and lunar phase) associated with upstream and downstream seasonal movements of yellow-phase eels near the Millville hydroelectric dam in the lower Shenandoah River drainage, West Virginia (an upper watershed of the Potomac River system). Secondary objectives were to estimate average seasonal distances traveled by eels from Millville Dam, and examine nocturnal movements of yellow-phase eels within the tailwater of the dam during summer.

\section{METHODS}

The study occurred within a $9 \mathrm{~km}$ section (average width $150 \mathrm{~m}$ ) of the lower Shenandoah River downstream of Millville Dam, West Virginia (Fig. 1). The $5 \mathrm{~m}$ high Millville Dam diverts water to a bypass canal for hydroelectric production. The bottom substrate of the $700 \mathrm{~m}$ tailwater section (immediately below the dam) is predominantly slanted bedrock, with some areas of small boulders, large cobble, and gravel. During low stream flows, exposed bedrock creates small pools and braided channels in several areas of the tailwater and lower kilometer of the study area. The middle section of the study area contains pool and run habitats with unexposed bedrock, boulder, cobble, and gravel substrates. A road parallels the upper $4 \mathrm{~km}$ section of the study area, whereas a footpath provides access to the lower $5 \mathrm{~km}$ section.

To obtain data on seasonal and nocturnal movements, 20 yellow-phase American eels were captured with a backpack electrofisher from the tailwater of Millville Dam. We anesthetized eels using a clove oil solution (Anderson et al. 1997) and surgically implanted radio transmitters (Lotek MBFT-5, 11mm x 43mm, 366-day battery life; Lotek Wireless Inc., Ontario, Canada) into the abdominal cavity (Ross and Kleiner 1982). Radio tags were implanted into 13 eels (range 518-810 mm) during 8-23 September 2001, and seven eels (range 599-781 mm) during11-27 June 2002. Eels were monitored 
for several hours post-surgery, and released near the collection area. Locations of radiotagged eels (tracked manually with a Lotek SRX_400 receiver and Yagi antenna) were triangulated using compass bearings and DeLorme 3-D TopoQuads ${ }^{\circledR}$ mapping software Delorme, Yarmouth, Maine, USA. Error of triangulated locations was $<5 \mathrm{~m}$ based on electrofishing recaptures of radio-tagged eels. We measured straight-line distances (i.e. minimum distances) between consecutive relocation coordinates of each individual eel. In cases where river sinuosity prevented straight-line distances, we measured the withinriver minimum distance between relocations.

\section{Seasonal movements}

For analysis of seasonal movements, we tracked eels during daylight hours from 10 fixed stations within a $4 \mathrm{~km}$ section of shoreline below the dam. When eels were not relocated from fixed stations, we tracked eels within the lower study area from non-fixed positions. Tracking dates were generally within one to two week intervals from 14 June 2001 to 28 May 2003, but several intervals between 15 to 33 days occurred during winter months because of severe weather conditions. Minimum distances during each time interval between relocations were expressed as $\mathrm{m} / \mathrm{day}$.

We used PROC MIXED (SAS 1990) to model covariance associated with repeated measures on individual eels, and analyzed upstream and downstream movements separately. Given unequal time intervals between relocations, we used the spatial power structure (a generalization of the autoregressive first-order covariance structure for equally spaced data) to address within-subject covariance (Littell et al. 1996), where "eel nested within season" was the experimental unit. Relocation times between eels were temporally aligned to account for missing values (Littell et al. 1996). Mixed models included season as a fixed effect, where seasons were partitioned as spring (16 March-15 June), summer (16 June-15 Sept), fall (16 Sept-15 Dec), and winter (16 Dec-15 March). Using the spatial power structure of covariance, least-square means in PROC MIXED (Littell et al. 1996) estimated means of upstream and downstream movements by season.

Seasonal movements were modeled with seven covariates derived from water temperature, stream flow, and lunar phase. Onset ${ }^{\circledR}$ temperature loggers (Onset 
Computer Corporation, Pocasset, Massachusetts, USA) recorded daily water temperatures within the study area from the main channel Shenandoah River and one small tributary (Fig. 1). River flows (cubic meters per second, cms) were obtained from the U.S. Geological Survey gage at Millville Dam (http://waterdata.usgs.gov). We used the fraction of the moon's visible disc to quantify lunar illumination, where fractions range from new moon (0.00), first and last quarter (0.50), and full moon (1.00; http://aa.usno.navy.mil/data/docs/MoonFraction.html). For each time interval between relocations, covariates were determined as (1) maximum values of lunar illumination, stream flow, and water temperature, and (2) mean values of stream flow and water temperature. Covariates of maximum values were used to model the importance of extreme conditions, whereas those of mean values were used to represent general conditions within relocation intervals. Covariates derived from differences in mean water temperatures and stream flows between consecutive relocation intervals were used to model fluctuations or sudden changes within short time periods.

Although a large number of models could be fit to the data, given all potential combinations and interactions between season and covariates, we selected 24 models based on published literature of fish movements. Given the limits of our effective sample size, we avoided models with higher than 10 estimable parameters (Burnham and Anderson 2003). The 24 biologically-reasonable candidate models (selected before analysis and representing multiple hypotheses, Chamberlin 1965) were ranked by the second-order adjustment to Akaike's information criterion $\left(\mathrm{AIC}_{c}\right)$. This informationtheoretic approach, where $\mathrm{AIC}_{c}$ estimates Kullback-Leibler distance, selects the best model (or suite of competing models) through a parsimonious tradeoff among bias, variance, and the number of estimable model parameters, and avoids the use of arbitrary significance (alpha) levels for inference from observational data (Burnham and Anderson 2003).

\section{Distances from dam}

We calculated distances between coordinates of eel relocations and Millville Dam to determine seasonal locations of eels relative to the dam. Using the spatial power structure to model within-subject covariance, least-square means in PROC MIXED 
(Littell et al. 1996) estimated mean distances from the dam by season. The mixed model included season as a fixed effect, with "eel nested within season" as the experimental unit. We accounted for missing values and unequal time intervals between locations with methods described above.

\section{Nocturnal movements}

We estimated nocturnal movements of eight eels (518-781 mm TL) within the 700 m tailwater of Millville Dam during six nights (25-26, 29-30, and 30-31 July 2002 and 1-2, 6-7, and 8-9 August 2002). Movements (m/hr) were estimated within four 2hour time periods (2100-2300, 2300-0100, 0100-0300, and 0300-0500 hours) on each night. Lunar illumination (as described above), stream flow, and water temperature were recorded for each 2-hour relocation interval, but water temperature and stream flow were not used as environmental covariates given little variation among nights. To address covariance, we fit the full model (Date x Time) with unstructured, compound symmetry, and first-order autoregressive covariance models using PROC MIXED (Littell et al. 1996), and selected the best model based on the lowest $\mathrm{AIC}_{c}$ value. Using the best covariate model, a set of five candidate models were fit to the nocturnal movement data and represented alternative hypotheses of eel movements associated with dusk (21002300 hours), dawn (0300-0500 hours), dusk and dawn combined, and lunar illumination. For statistical inference, we used $\mathrm{AIC}_{c}$ to select the best model or models supported by the data.

\section{RESULTS}

Sixteen of the 20 radio-tagged American eels were positioned 471 times during the 617-day study period, with only one location recorded per each tagged eel on each tracking day. Not all tagged eels were relocated on each tracking day, and four eels were not relocated after release (possibly due to transmitter failure or movement from the study area). To reduce bias from tag-induced movements, we removed the first 30 days of relocation data, because eels moved erratically upstream and downstream during the first three weeks after surgery. 


\section{Seasonal movements}

Movements differed among seasons with highest rates of upstream movement during spring and highest rates of downstream movement during fall. Models without a seasonal effect were unsupported by the data (Table 1). For analysis of upstream movements, $\mathrm{AIC}_{c}$ selected Season $\mathrm{x}$ Maximum Flow as the best model, but two additive models (with temperature fluctuation and/or flow fluctuation) and two interaction models (with average flow and flow fluctuation) were close competitors (Table 1). Based on the five competing "best" models, our data supported an association of higher flows and increasing temperatures with upstream movements during spring. During spring, upstream movements $(0=33.8 \mathrm{~m} /$ day, $\mathrm{SE}=4.1)$ exceeded downstream movements $(0=$ $11.0 \mathrm{~m} /$ day, $\mathrm{SE}=2.5)$, and co-occurred with water temperatures above $15^{\circ} \mathrm{C}$ and increased stream flows. Models with a lunar illumination covariate received little weight for the analysis of upstream movements (Table 1).

Lunar illumination was associated with downstream movements, where the two best models (supported by lowest $\mathrm{AIC}_{C}$ values) were Season $x$ Lunar Illumination and Season + Lunar Illumination + Average Water Temperature (Table 1). These models reflected the importance of a lower illuminated fraction of the moon's visible surface (i.e., darker nights) and decreasing water temperatures on downstream movements during fall $(0=18.4 \mathrm{~m} /$ day, $\mathrm{SE}=2.9)$. During fall, the longest downstream movements $(>50$ m) within relocation intervals occurred within a narrow range of mean water temperatures $\left(11.0-11.6^{\circ} \mathrm{C}\right)$. Upstream movements of eight individuals (range $32-363$ m) during a 7-day relocation interval (2 Nov 2001 to 9 Nov 2001) influenced the relatively high mean rate of upstream movement during fall $(0=12.4 \mathrm{~m} / \mathrm{day}, \mathrm{SE}=5.3)$. These large upstream movements during 2 Nov 2001 to 9 Nov 2001 occurred on a waning full moon with flow $(0=12.2 \mathrm{cms}$, maximum $=12.7 \mathrm{cms})$ and water temperature $\left(0=9.1{ }^{\circ} \mathrm{C}\right.$, maximum $\left.=9.3^{\circ} \mathrm{C}\right)$ relatively unchanged from the previous time interval.

Movements during summer exceeded those of winter, but were less than upstream movements in spring and downstream movements during fall. During summer, localized movements occurred within mean water temperatures of $24.1-29.9^{\circ} \mathrm{C}$, where eels wandered upstream $(0=10.5 \mathrm{~m} /$ day, $\mathrm{SE}=4.1)$ and downstream $(0=11.5 \mathrm{~m} /$ day, $\mathrm{SE}=$ 1.7). Winter movements were lowest of all seasons (upstream, $0=2.1 \mathrm{~m} / \mathrm{day}, \mathrm{SE}=6.6$; 
downstream, $0=3.5 \mathrm{~m} /$ day, $\mathrm{SE}=2.4$ ), and were observed within a mainstem water temperature range of $0.8-9.4^{\circ} \mathrm{C}$. Most of the tagged eels overwintered in thermal refuge areas near tributary mouths. Winter water temperatures at one tributary mouth (Fig. 1) averaged $7.2^{\circ} \mathrm{C}$, whereas main channel temperatures averaged $3.7^{\circ} \mathrm{C}$.

\section{Nocturnal movements}

The compound symmetry covariance model was supported by the data (based on lowest $\mathrm{AIC}_{c}$ ) and was use to estimate means of nocturnal movements. Eels moved erratically (upstream and downstream) during $2100-0500 \mathrm{hrs}$ on six summer nights, with an overall mean movement estimate of $10.2 \mathrm{~m} / \mathrm{hr}(\mathrm{SE}=0.48)$. Data supported the combined dusk and dawn model (Table 2), where nocturnal movements were greatest during dusk $(2100-2300 \mathrm{hrs},(0=10.1 \mathrm{~m} / \mathrm{hr}, \mathrm{SE}=0.75)$ and dawn $(0300-0500 \mathrm{hrs},(0=$ $11.4 \mathrm{~m} / \mathrm{hr}, \mathrm{SE}=0.75)$, and slightly less during $2300-0100(0=9.7 \mathrm{~m} / \mathrm{hr}, \mathrm{SE}=0.75)$ and 0100-0300 hrs $(0=9.6 \mathrm{~m} / \mathrm{hr}, \mathrm{SE}=0.75)$. Despite a wide range of lunar illumination among the six nights $(0.0-0.97)$, data did not support an association between movements and lunar illumination (Table 2). Water temperature and stream flow were not modeled as covariates in the analysis of nocturnal movements, given low variation in water temperature (range $26.4-30.4^{\circ} \mathrm{C}$ ) and stream flow (range $11.8-18.7 \mathrm{cms}$ ) among the six summer nights, with less variation among time intervals during each night.

\section{Seasonal downstream distances from the dam}

Distances of eels downstream from Millville Dam corroborated seasonal movements. Eels were farthest from the dam during fall $(0=1347 \mathrm{~m}, \mathrm{SE}=287)$ and winter $(0=1954 \mathrm{~m}, \mathrm{SE}=307)$, and closest during spring $(0=1014 \mathrm{~m}, \mathrm{SE}=293)$ and summer $(0=831 \mathrm{~m}, \mathrm{SE}=295$; Figure 2$)$. Radio-tagged eels were closest to the dam ( 0 $=615 \mathrm{~m}, \mathrm{SE}=102)$ after water temperatures exceeded $15^{\circ} \mathrm{C}$ during late spring (26 April -10 June). Several eels were located at the base of the dam during spring and summer, but were re-located downstream on subsequent visits. During early fall (18 September 25 October) eels were also relatively close to the dam $(0=1200 \mathrm{~m}, \mathrm{SE}=220)$ when water temperatures exceeded $12^{\circ} \mathrm{C}$. The large effect sizes in mean distances from the dam, between early fall and winter (1200 vs.1954 m) and winter and late spring (1954 vs. 
$615 \mathrm{~m})$, reflect downstream movements during fall and upstream movements during spring.

\section{DISCUSSION}

Our data supported an association between upstream migration of large (range 518 - $810 \mathrm{~mm}$ TL) yellow-phase American eels and two abiotic variables (water temperature and stream flow) during spring. Given relatively warm spring rains, stream flow and water temperature increase concurrently during spring, and may synergistically influence upstream migration. In this study, sudden changes in stream flow and water temperature influenced upstream migration of large yellow-phase eels during spring. Water temperature of $15^{\circ} \mathrm{C}$ cued upstream migration in the lower Shenandoah River, and is bracketed by the range of temperature cues $\left(10-16^{\circ} \mathrm{C}\right)$ from eel studies summarized by EPRI (1999). Upstream migration during spring was expected, based on similar findings by Sorensen and Bianchini (1986), Haro and Krueger (1988), and Jessop (2003). Studies of eel movements, however, have largely focused on elvers or small yellow-phase eels in lower sections of coastal rivers, and less information is available on movements of large yellow-phase eels in upper sections of rivers.

The general pattern of downstream movements of large yellow-phase eels during fall (with some periods of upstream movement) probably reflects downstream and upstream searches for overwintering areas. Downstream movements during fall occurred on darker nights (near new moons) and during decreasing water temperatures, with largest movements during relocation intervals with mean water temperatures of $11.0-$ $11.6^{\circ} \mathrm{C}$. Although nocturnal movements of eels are well documented (Lowe 1952; Tecsh 1977; Dutil et al. 1988), contrasted results exist for movements associated with lunar phase (see review by Cairns and Hooley 2003). Our data support an association between low levels of lunar illumination and downstream movements of yellow-phase eels during fall. Upstream movements during fall may represent upstream migration instead of searches for suitable winter habitats, where retreat to overwintering areas below the dam possibly occurred after unsuccessful attempts at upstream migration. A period of upstream migration occurs during fall on the St. Lawrence River (Dutil et al. 1989, McGrath et al. 2003). Smaller yellow-phase eels move upstream during late summer in the lower Shenandoah River; an eel ladder installed at Millville Dam on 31 July 2003 
passed 408 eels $(0=304 \mathrm{~mm}$ TL, range 197-510 mm TL) during 22 August $2003-17$ September 2003 (unpublished data).

Eel locations determined at 1 - to 2 -week intervals did not indicate directional upstream or downstream migration during summer, but supported erratic wandering movements in upstream or downstream directions. Movement data from night tracking at 2-hr intervals also supported localized movements. Eels may establish small home ranges during summer (Gunning and Shoop 1962, Ford and Mercer 1986, Bozeman et al. 1985), and eels in this study remained within relatively short river sections in the lower Shenandoah River during summer. We did not estimate home range sizes from summer movement data, given dam-induced bias on upstream movements. In our study, nocturnal wandering during summer probably reflects active foraging, because yellowphase eels feed primarily at night (Sorensen et al. 1986). Although food availability may influence movements (Helfman 1986), large foraging areas were unlikely in our study area, given large populations of crayfish and cyprinids. Crayfish are common diet items of eels in this region (Lookabaugh and Angermeier 1992), and were consumed by eels within this study area, based on crayfish parts excreted during surgical-implantation of radio tags.

Yellow-phase American eels become torpid at water temperatures below $10^{\circ} \mathrm{C}$ (Walsh et al. 1983); hence, we expected no movements during winter seasons of our study, where water temperatures ranged from 0.8-9.4 ${ }^{\circ} \mathrm{C}$. Nyman (1972) and Barila and Stauffer (1980) reported reduced feeding of eels at water temperatures below $14^{\circ} \mathrm{C}$, whereas Renaud and Moon (1980) reported feeding cessation and reduced activity of eels below $8^{\circ} \mathrm{C}$. Euston et al. (1998), however, reported downstream movements of silverphase eels at water temperatures as low as $6{ }^{\circ} \mathrm{C}$. In our study, estimates of small upstream $(0=2.1 \mathrm{~m} /$ day $)$ and downstream $(0=3.5 \mathrm{~m} /$ day $)$ movements during winter probably represent errors in triangulation of relocation coordinates. Most individuals moved less than $5 \mathrm{~m}$ between relocations during winter. During the time interval from $1-18$ Dec $2001\left(0=5.1^{\circ} \mathrm{C}\right)$, relatively large downstream movements $(11$ and $20 \mathrm{~m})$ of two individuals possibly represent displacement, given that maximum stream flow increased from 15 to $22 \mathrm{cms}$ during this time period. Movement data, however, did not support downstream displacement of torpid eels during larger fluctuations in stream flow. We 
believe that larger mean distances from the dam during winter months reflect the location and use of thermal refugia near tributary mouths. Silver-phase European eels used areas of elevated water temperatures near thermal power plants during winter (Nyman 1975), and other riverine fishes use thermal refuge areas during winter (Raibley et al. 1997, Knights et al. 1995, Gent et al. 1995).

\section{Management implications}

Movements of yellow-phase American eels differed among seasons in the lower Shenandoah River, owing largely to upstream movements in spring, downstream movements during fall, wandering (upstream and downstream movements) during summer, and minimal movements during winter. Oliveira (1997) citing Bianchini et al. (1982) hypothesized that yellow-phase eels likely move long distances between periods of relatively little movement. Our data are consistent with this punctuated-movement hypothesis, where upstream movements occur during spring followed by localized movements during summer, and relatively little movement during winter. Our data are inconclusive concerning upstream migration of large yellow-phase eels during fall. Movement data from the lower Shenandoah River likely represent behavior of large yellow-phase eels within upper watersheds of other Atlantic coastal streams. From a management perspective, however, we restrict inference to movements of large yellowphase eels near dams.

Water temperature was important to overall seasonal eel movements, particularly as an environmental cue to upstream movement in spring (combined with increased stream flows). For large yellow-phase eels, our data support spring as the critical period for provision of upstream passage at hydroelectric dams. Data did not support other seasons (fall, winter, and summer) as important for upstream passage of large yellowphase eels (with the possible exception of fall). Water temperature (combined with darker nights near the new moon) cued downstream movement during fall. We believe that downstream movements during fall and larger distances from the dam during winter reflect locations and use of thermal refuge areas. Although direction of fall movements was generally downstream, a short period of upstream movements also occurred during fall. Possibly, eels settled for thermal refuge areas downstream of the dam after 
unsuccessful attempts of upstream migration. We did not find evidence of upstream migration of large yellow-phase eels during summer, where data from 1- to 2-week intervals and nocturnal data within 2-hour time intervals supported localized upstream and downstream movements.

Data from this study provide natural resource managers with a better understanding of the behavior of large yellow-phase American eels in upper watersheds of Atlantic coastal rivers. Additionally, the data are relevant to the operational management of hydroelectric facilities in relation to eel passage. Additional studies on relations between eel movements and dams in upper watersheds, however, are needed to further address seasonal upstream and downstream movements of small and large yellowphase American eels. Also, given a recent push for provision of upstream passage via eel ladders, further research is needed for dam passage of downstream migrant silver-phase American eels.

\section{LITERATURE CITED}

Anderson, W.G., R.S. McKinley, and M. Colavecchia. 1997. The use of clove oil as an anesthetic for rainbow trout and its effects on swimming performance. North American Journal of Fisheries Managment 17:301-307.

ASMFC (Atlantic States Marine Fisheries Commisssion). 2000. Interstate fishery management plan for American eel. Fishery Management Report 36, Washington, D.C.

Barbin, G. P., S. J. Parker, J. D. McCleave. 1998. Olfactory clues play a critical role in the esturine migration of silver-phase American eels. Environmental Biology of Fishes 53:283-291.

Barila, T. Y. and J. R. Stauffer, Jr. 1980. Temperature behavioral responses of the American eel, Anguilla rostrata (LeSueur), from Maryland. Hydrobiologia 74:4951.

Bianchini, M., P.W. Sorensen, and H.E. Winn. 1982. Stima dell'abbondanza e shemi di movimento a breve raggio della anguilla Americana, Anguilla rostrata (LeSueur)(Pisces, Apodes), nel Narrow River, Rhode Island, USA. Naturalista Siciliano (Supplement 4) 6:269-277. 
Bozeman, E.L., G.S. Helfman, and T. Richardson. 1985. Population size and home range of American eels in a Georgia tidal creek. Transactions of the American Fisheries Society 114:821-825.

Burnham, K. P. and D. R. Anderson. 2003. Model selection and multimodel inference: a practical information-theoretic approach, Second Edition. Springer, New York, New York.

Cairns, D.K. and P.J.D. Hooley. 2003. Lunar cycles of American eels in tidal waters of the southern Gulf of the St. Lawrence, Canada. Pages 265-274 in D.A. Dixon, editor. Biology, Management, and protection of catadromous eels. American Fisheries Society, Symposium 33, Bethesda, Maryland.

Chamberlin, T. C. 1965 (1890). The method of multiple working hypotheses. Science 148:754-759. (Reprint of 1890 paper in Science).

Dutil, J.-D., A. Giroux, A. Kemp, G. LaVoie, and J.-P. Dallaire. 1988. Tidal influence on movements and on daily cycle of activity of American eels. Transactions of the American Fisheries Society 117:488-494.

Dutil, J.-D., M. Michaud, and A. Giroux. 1989. Seasonal and diel patterns of stream invasion by American eels (Anguilla rostrata) in the northern Gulf of St. Lawrence. Canadian Journal of Zoology 67:182-188.

Durif, C., P. Elie, C. Gosset, J. Rives, and F. Travade. 2003. Behavioral study of downstream migrating eels by radio-telemetry at a small hydroelectric power plant. Pages 343-356 in D.A. Dixon, editor. Biology, Management, and protection of catadromous eels. American Fisheries Society, Symposium 33, Bethesda, Maryland.

EPRI (Electrical Power Research Institute). 1999. American eel (Anguilla rostrata) scooping study: a literature and data review of life history, stock status, population dynamics, and hydroelectric impacts. EPRI, Palo Alto, California: TR111873.

Euston, E.T., D.D. Royer, and C.L. Simons. 1998. American eels and hydro plants: clues to eel passage. Hydro Review (August):94-103. 
Ford, T. E. and E. Mercer. 1986. Density, size distribution and home range of American eels, Anguilla rostrata, in a Massachusetts Salt Marsh. Environmental Biology of Fishes 17:309-314.

Gent, R., J. Pitlo, Jr., and T. Boland. 1995. Largemouth bass response to habitat and water quality rehabilitation in a backwater of the upper Mississippi River. North American Journal of Fisheries Management 15: 784-793.

Goodwin, K. R. and P. L. Angermeier. 2003. Demographic characteristics of the American eel in the Potomac River drainage, Virginia. Transactions of the American Fisheries Society 132:524-535.

Groom, W. 1975. Elver observations in New Brunswick's Bat of Fundy Region. Resource Development Branch, N. B. Department of Fisheries, Fredericton, New Brunswick, Canada.

Gunning, G.E. and C.R. Shoop. 1962. Restricted movements of the American eel, Anguilla rostrata (LeSueur), in freshwater streams, with comments on growth rate. Tulane Studies in Zoology 9:265-272.

Haro, A.J. and W.H. Krueger. 1987. Pigmentation, otolith rings, and upstream migration of juvenile American eels (Anguilla rostrata) in a coastal Rhode Island stream. Canadian Journal of Zoology 69:812-814.

Haro, A. J. and W. H. Krueger. 1988. Pigmentation, size and migration of elvers (Anguilla rostrata (LeSueur)) in a coastal Rhode Island stream. Canadian Journal of Zoology 66:2528-2533.

Haro, A., W. Richkus, K. Whalen, A. Hoar, W-D. Busch, S. Lary, T. Brush, and D. Dixon. 2000. Population decline of the American eel: implications for research and management. Fisheries 25(9):7-16.

Helfman, G. S., D. L. Stoneburner, E. L. Bozeman, P. A. Christian, and A. Whalen. 1983. Ultrasonic telemetry of American eel movements in a tidal creek. Transactions of the American Fisheries Society 112:105-110.

Helfman, G.S. 1986. Diel distribution and activity of American eels (Anguilla rostrata) in a cave-spring. Canadian Journal of Fisheries and Aquatic Science 43:15951605. 
Hurley, D. A. 1972. The American eel (Anguilla rostrata) in eastern Lake Ontario. Journal of the Fisheries Research Board of Canada 29:535-543.

Jenkins, R. E. and N. M. Burkhead. 1993. Freshwater fishes of Virginia. American Fisheries Society, Bethesda, Maryland.

Jessop, B.M. 1987. Migrating American eels in Nova Scotia. Transactions of the American Fisheries Society 116:161-170.

Jessop, B.M. 2003. Annual variability in the effects of water temperature, discharge, and tidal stage on the migration of American eel elvers from estuary to river. Pages 316 in D.A. Dixon, editor. Biology, Management, and protection of catadromous eels. American Fisheries Society, Symposium 33, Bethesda, Maryland.

Knights, B. C., D. L. Johnson, and M. H. Sandheinrich. 1995. Responses of bluegills and black crappie to dissolved oxygen, temperature, and current in backwater lakes of the Upper Mississippi River during winter. North American Journal of Fisheries Management 15: 390-399.

LaBar, G. W. and D. E. Facey. 1983. Local movements and inshore population sizes of American eels in Lake Champlain, Vermont. Transactions of the American Fisheries Society 112:111-116.

Lamothe, P. J., M. Gallagher, D. P. Chivers, and J. M. Moring. 2000. Homing and movement of yellow-phase American eels in freshwater ponds. Environmental Biology of Fishes 58:393-399.

Levesque, J. R. and W. R. Whitworth. 1987. Age class distribution and size of American eel (Anguilla rostrata) in the Shatucket/Thames River, Connecticut. Journal of Freshwater Ecology 4(1):17-22.

Littell, R.C., G.A. Miliken, W.W. Stroup, and R.D. Wolfinger. 1996. SAS system for mixed models. SAS Institute, Cary, North Carolina.

Lookabaugh, P. S. and P. L. Angermeier. 1992. Diet patterns of American Eel, Anguilla rostrata, in the James River drainage, Virginia. Journal of Freshwater Ecology 7(4):425-434.

Lowe, R. H. 1952. The influence of light and other factors on the seaward migration of the silver eel, Anguilla anguilla L. Journal of Animal Ecology 21:275-309. 
McGrath, K.J., D. Desrochers, C. Fleury, and J.W. Dembeck, IV. 2003. Studies of upstream migrant American eels at the Moses-Saunders Power Dam on the St. Lawrence River near Massena, New York. Pages 153-166 in D.A. Dixon, editor. Biology, Management, and protection of catadromous eels. American Fisheries Society, Symposium 33, Bethesda, Maryland.

Menhinick, E.F. 1991. The freshwater fishes of North Carolina. North Carolina Wildlife Resources Commission, Raleigh, North Carolina.

Nyman, L. 1972. Some effects of temperature on eel (Anguilla) behavior. Report, Institute of Freshwater Research, Drottningholm, Sweden 52:90-102.

Nyman, L. 1975. Behaviour of fish influenced by hotwater effluents as observed by ultrasonic tracking. Report, Institute of Freshwater Research, Drottningholm, Sweden 54:63-74.

Oliveira, K. 1997. Movements and growth rates of yellow-phase American eels in the Annaquatucket River, Rhode Island. Transactions of the American Fisheries Society 126:638-646.

Raibley, P. T., K. S. Irons, T. M. O’Hara, K. D. Blodgett, and R. E. Sparks. 1997. Winter habitat used by largemouth bass in the Illinois River, a large riverfloodplain ecosystem. North American Journal of Fisheries Management 17: 401-412.

Renaud, J.M. and T.W. Moon. 1980. Characterization of gluconeogenesis in hepatocytes isolated from the American eel, Anguilla rostrata LeSueur. Journal of Comparative Physiology B135:115-125.

Richkus, W. and K. Whalen. 2000. Evidence for a decline in abundance of American eel, Anguilla rostrata (LeSueur), in North America since the early 1980s. Dana 12:83-97.

Richkus, W.A. and D.A. Dixon. 2003. Review of research and technologies on passage and protection of downstream migrating catadromous eels at hydroelectric facilities. Pages 377-388 in D.A. Dixon, editor. Biology, Management, and protection of catadromous eels. American Fisheries Society, Symposium 33, Bethesda, Maryland. 
Ross, M.J. and C.F. Kleiner. 1982. Shielded-needle technique for surgically implanting radio-frequency transmitters in fish. The Progressive Fish-Culturist 44:41-43.

SAS (Statistical Analysis System). 1990. SAS/ STAT user's guide, version 6 ( $4^{\text {th }}$ edition). SAS Institute, Cary, North Carolina.

Smith, M. W. and J. W. Saunders. 1955. The American eel in certain fresh waters of the Maritime Provinces of Canada. Journal of the Fisheries Research Board of Canada 12:238-269.

Sorenson, P.W. and M.L. Bianchini. 1986. Environmental correlates of the freshwater migration of elvers of the American eel in a Rhode Island brook. Transactions of the American Fisheries Society 115:258-268.

Sorenson, P.W., M.L. Bianchini, and H.E. Winn. 1986. Diel foraging activity of American eels, Anguilla rostrata (LeSueur), in a Rhode Island estuary. Fishery Bulletin 84:746-747.

Tecsh, F.-W. 1977. The eel. Chapman and Hall Ltd., London, England.

Verdon, R. and D. Desrochers. 2003. Upstream migratory movements of American eel Anguilla rostrata between the Beauharnois and Moses-Saunders power dams on the St. Lawrence River. Pages 139-152 in D.A. Dixon, editor. Biology, Management, and protection of catadromous eels. American Fisheries Society, Symposium 33, Bethesda, Maryland.

Verdon, R., D. Desrochers, and P. Dumont. 2003. Recruitment of American eels in the Richelieu River and Lake Champlain: provision of upstream passage as a regional-scale solution to a large-scale problem. Pages 125-138 in D.A. Dixon, editor. Biology, Management, and protection of catadromous eels. American Fisheries Society, Symposium 33, Bethesda, Maryland.

Walsh, P.J., G.D. Foster, and T.W. Moon. 1983. The effects of temperature on metabolism of the American eel Anguilla rostrata (LeSueur): compensation in the summer and torpor in the winter. Physiological Zoology 56:532-540.

Winn, H. E., W. A. Richkus, and L. K. Winn. 1975. Sexual dimorphism and natural movements of the American eel (Anguilla rostrata) in Rhode Island streams and estuaries. Helgoländer Wissenschaftliche Meeresuntersuchungen 27:156-166. 
Figure 1. Study area within a $9 \mathrm{~km}$ section of the lower Shenandoah River, West Virginia, from Millville Dam to the mouth of the Shenandoah River.

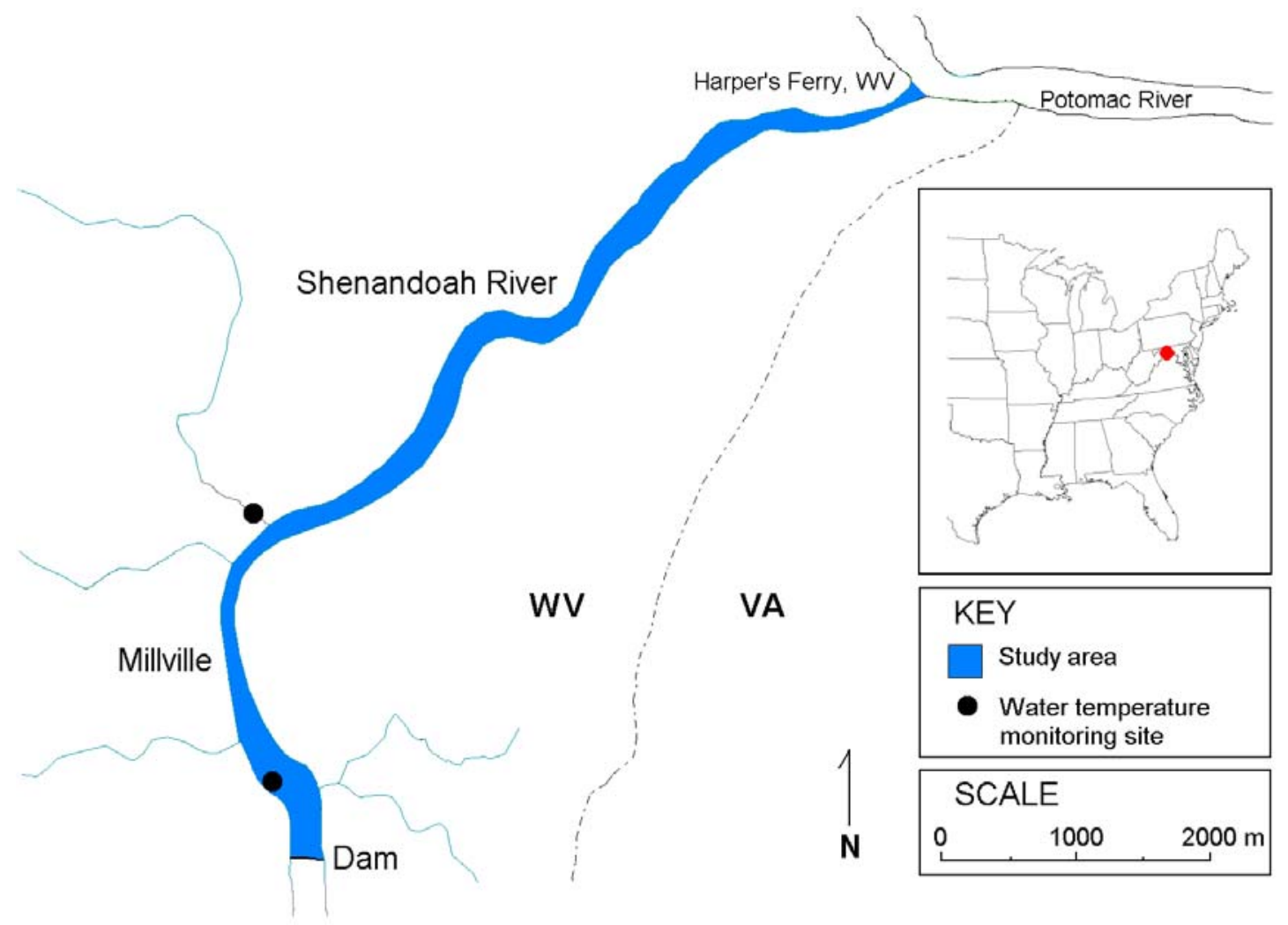


Figure 2. Seasonal distance of radio-tagged American eels from Millville Dam (all relocations plotted for each eel).

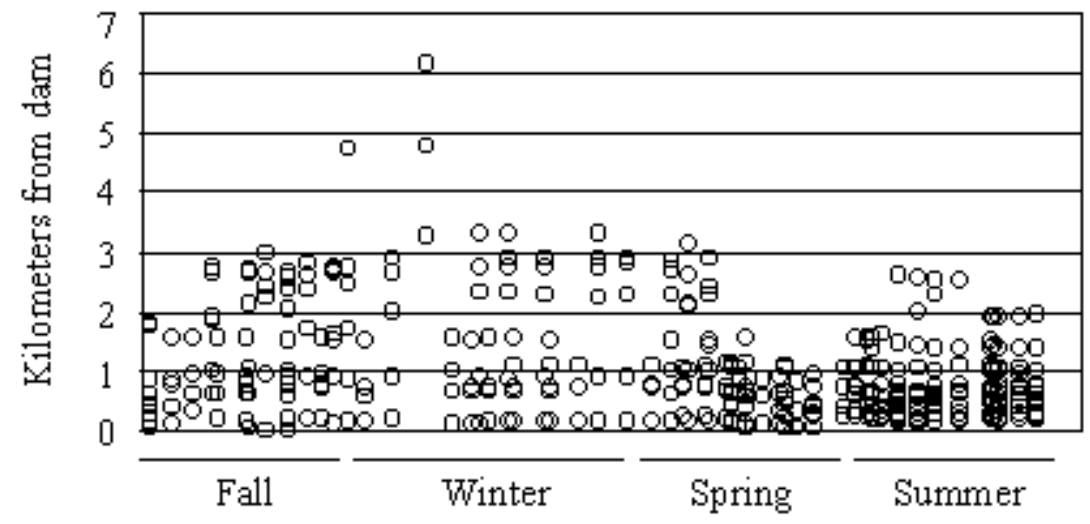


Table 1. Selection statistics for 24 alternative models from separate analyses of upstream and downstream movements; second order adjustment of Akaike's Information Criterion $\left(\mathrm{AIC}_{c}\right)$, distance from lowest $\mathrm{AIC}_{c}\left(\Delta_{i}\right)$, and Akaike weights $\left(\mathrm{w}_{i}\right)$. Bold weights represent competing models within each analysis; statistics between upstream and downstream analyses are not comparable. Model variables include season (movements partitioned by spring, summer, fall, and winter), and six covariates determined from each relocation interval: maximum and mean stream flow, maximum and mean water temperature, maximum lunar illumination, and fluctuations of stream flow and water temperature.

Model

Season x Lunar Illumination

Season + Mean Flow + Lunar Illumination

Season + Maximum Flow + Lunar Illumination

Season + Mean Temperature + Lunar Illumination

Season + Lunar Illumination

Season x Mean Flow

Season + Mean Flow

Season x Maximum Flow

Season + Maximum Flow

Season x Mean Temperature

Season + Mean Temperature

Season + Mean Temperature + Mean Flow

Season x Flow Fluctuation

Season + Flow Fluctuation

Season x Temperature Fluctuation

Season + Temperature Fluctuation

Season + Temperature Fluctuation + Flow Fluctuation

Season

Lunar Illumination

Mean Flow

Maximum Flow

Mean Temperature

Flow Fluctuation

Temperature Fluctuation
Upstream movements

$\begin{array}{ccc}\mathrm{AIC}_{c} & \Delta_{i} \quad \mathrm{w}_{i}\end{array}$

567.5

568.1

566.0

566.5

561.6

568.9

560.6

569.1

571.6

567.4

569.5

563.5

564.8

565.4

561.5

561.4

567.1

597.0

601.0

602.1

597.9

597.2

599.4
Downstream movements

$\begin{array}{ccc}\mathrm{AIC}_{c} & \Delta_{i} & \mathrm{~W}_{i}\end{array}$

\section{(1)}


Table 2. Selection statistics for 5 alternative models of nocturnal movements during six summer nights; second order adjustment of Akaike's Information Criterion $\left(\mathrm{AIC}_{c}\right)$, distance from lowest $\operatorname{AIC}_{c}\left(\Delta_{i}\right)$, and Akaike weights $\left(\mathrm{w}_{i}\right)$. Movements $(\mathrm{m} / \mathrm{hr})$ were estimated within four 2-hour time periods (2100-2300, 2300-0100, 0100-0300, and 03000500 hours), where models represent movements associated with dusk (2100-2300 hours), dawn (0300-0500 hours), dusk and dawn, and lunar illumination.

\begin{tabular}{lccc} 
& \multicolumn{3}{c}{ Nocturnal movements } \\
Model & $\mathrm{AIC}_{c}$ & $\Delta_{i}$ & $\mathrm{w}_{i}$ \\
\hline & & & \\
Dusk/dawn & 371.9 & 0.0 & 0.54 \\
Dawn & 373.1 & 1.2 & 0.29 \\
Lunar Illumination & 375.7 & 3.8 & 0.08 \\
Dusk & 375.8 & 3.9 & 0.08 \\
Date & 379.2 & 7.3 & 0.01 \\
& & & \\
\hline
\end{tabular}

